\title{
PENGARUH PENYERAPAN RADIASI SURYA PADA ME- DIA TIPE KOTAK DAN BERGELOMBANG BERBAHAN DASAR STAINLESS STEEL TERHADAP KEMAMPUAN DESTILASI AIR PAYAU DI PESISIR PANTAI SEBA
}

\author{
Dedy Nataniel Ully ${ }^{1}$, Rokhyadi $^{2}$, Duma Pabiban ${ }^{3}$
}

\begin{abstract}
Abstrak :
Penggunaan penyerap radiasi surya pada media tipe kotak dan bergelombang dapat meningkatkan kemampuan atau kinerja dari proses destilasi air payau menjadi air tawar. Proses destilasi air payau ini adalah untuk memisahkan unsur garam yang berlebihan yang terdapat di dalam air payau, dengan cara dipanaskan dengan menggunakan energi matahari sehingga terjadi penguapan di dalam destilator dan pada kondisi tertentu akan mengalami pengembunan atau kondensasi, sehingga uap panas tadi berubah fasa menjadi air karena bersentuhan dengan permukaan kaca yang dingin. Dengan demikan, maka akan didapatkan air yang bersih dan tidak asin lagi. Sedangkan air asin akan tertinggal di dalam wadah destilator karena terdapat unsur garam di mana memiliki berat jenis yang lebih besar. Penelitian ini dilakukan dengan menggunakan metode eksperimental nyata (true experimental) pada skala laboratorium. Pengujian dilakukan pada pukul 8.00 sampai dengan pukul 16.00 dengan volume air di dalam destilator sebanyak 35 liter. Hasil penelitian menunjukkan bahwa efisiensi meningkat secara parabolik seiring bertambahnya waktu namun mengalami penurunan di atas pukul 14.00. Hal ini terjadi karena intensitas radiasi matahari akan semakin berkurang seiring dengan condongnya matahari ke arah barat, sehingga panas yang diterima oleh destilator semakin berkurang. Efisiensi tertinggi terjadi pukul 12.00 yakni pada penyerap tipe kotak sebesar $16.72 \%$ sedangkan pada penyerap tipe bergelombang efisiensi tertinggi juga terjadi pada pukul 12.00 yakni sebesar $12.509 \%$, hal ini terjadi karena pada saat inilah matahari memancarkan radiasi suryanya secara maksimal.
\end{abstract}

Kata kunci: Air payau, Destilasi, Penyerap dan Energi Matahari.

\begin{abstract}
:
The use of solar radiation absorber on box and corrugated media can improve the ability or performance of the brackish water distillation process into freshwater. This process of brackish water distillation is to separate the excessive salt elements contained in brackish water, by heating by using solar energy so that evaporation takes place within the distillator and under certain conditions will experience condensation, so that the hot vapor turns phase into water because it comes into contact with a cold glass surface. Thus, the water will be obtained clean and not salty anymore. While salt water will be left in the container destilator because there are elements of salt in which have a larger density. This study was conducted using real experimental method
\end{abstract}


(true experimental) on laboratory scale. The test is done at 8:00 until 16:00 with the volume of water in the distillator as much as 35 liters. The results show that efficiency increases in parabolic over time but decreases above at 14.00. This happens because the intensity of solar radiation will decrease along with the sun's incline to the west, so the heat received by the destilator decreases. The highest efficiency occurs at 12.00 ie on the absorbent type of box of $16.72 \%$ while the absorbent type of wave surges highest efficiency also occurs at 12:00 at 12.509\%, this happens because at this time the sun radiates suryanya maximum.

Keywords: Brackish Water, Distillation, Absorbent and Solar Energy.

\section{PENDAHULUAN}

Pengembangan destilasi air payau sudah banyak dilakukan dengan menggunakan energi matahari dengan berbagai perubahan baik dari bentuk atau geometri maupun instrumen lain seperti plat penyerap yang terdapat di dalam destilator. Plat penyerap yang umum digunakan adalah tipe plat datar. Penyerap tipe plat datar ini memiliki keuntungan yaitu proses pembuatan dan pemasangan yang sangat sederhana. Namun, penyerap plat datar ini juga memiliki kekurangan yaitu panas yang diserap hanya sedikit saja karena luasan dari plat datar yang memenuhi ruang di dalam destilator hanya seluas ruang destilator saja. Sementara itu, bila plat penyerap dibuat dengan penampang seperti kotak dan bergelombang maka luasan dari penyerap memungkinkan untuk lebih besar dari plat datar. Penggunaan penyerap tipe kotak dan bergelombang berbahan dasar stainless steel diharapkan dapat menyerap panas lebih besar. Hal ini terjadi karena penyerap tipe kotak dan bergelombang memiliki luasan yang lebih besar dan bahan penyerap yang terbuat dari stainless steel jauh lebih baik dalam hal penyerapan panas bila dibandingkan dengan bahan lain seperti seng atau aluminium. Penggunaan stainless steel sebagai plat penyerap juga memiliki keuntungan tersendiri yaitu tidak terjadinya korosi atau karat, sehingga dapat dipakai dalam waktu yang lama. Hal ini dilakukan sebagai upaya untuk meningkatkan performa atau kinerja dari destilasi air payau menjadi air tawar yang layak untuk dikonsumsi.

Upaya peningkatan performa atau kinerja telah dilakukan oleh peneliti sebelumnya yaitu dengan melakukan penelitian tentang pengaruh kecepatan angin terhadap produktivitas air kondesat pada peralatan destilasi. Pengambilan data dilakukan pada temperatur absorber, kaca penutup, kecepatan angin, radiasi matahari dan produksi air bersih. Hasil penelitian produksi air bersih pada peralatan destilasi air laut dengan menggunakan tenaga surya dengan pengaruh kecepatan angin dan menggunakan kaca penutup satu sisi rata-rata menghasilkan 21,68 $\mathrm{ml} /$ hari dengan efisiensi rata-rata 20,95\%. Semakin besar kecepatan angin yang didapat dan kenaikan temperatur air dalam basin akan menghasilkan jumlah produksi air kondensat lebih banyak [1].

Selanjutnya, dilakukan penelitian tentang rancang bangun alat konversi air laut menjadi air minum dengan proses destilasi sederhana menggunakan pemanas elektrik. Penelitian dilakukan di laboratorium dengan pengambilan sampel di sekitar pantai terdekat dan lama waktu penelitian selama 3 bulan dari juli 2012 hingga oktober 2012, dengan metode eksperimental. Hasil penelitian menunjukkan proses pemanasan air laut memakan waktu \pm 14 menit sebelum terjadinya penguapan sehingga membuat proses penguapan menjadi kurang efisien; Air yang dihasilkan bisa langsung dikonsumsi karena telah melewati proses pemanasan hingga $110^{\circ} \mathrm{C}$ yang mematikan bakteri, kuman dan senyawa biologis lainnya. Juga dengan adanya proses destilasi, tingkat salinitas dan kadar $\mathrm{pH}$ air sudah sesuai dengan standar air siap minum yang sehat [2].

Selanjutnya, penelitian dilakukan tentang kajian eksperimental untuk meningkatkan performansi destilasi surya basin tiga tingkat dengan menggunakan beberapa bahan 


\section{Jurnal Ilmiah FLASH $\quad$ Volume 3 Nomor 2 Desember 2017}

penyimpan panas. Tujuan penelitian ini adalah untuk meningkatkan prestasi dari alat destilasi surya basin tiga tingkat dengan menggunakan berbagai bahan penyimpan panas (aluminium, stainless steel dan seng), alat uji destilasi surya ini dapat berproduksi terus menerus selama 24 jam. Hasil pengujian menunjukkan pemakaian stainlees steel sebagai penyimpan panas dapat menghasilkan produktivitas air bersih lebih tinggi dibandingkan dengan bahan penyimpan panas dari seng dan aluminium [3].

Selanjutnya, dilakukan penelitian tentang pengaruh penggunaan preheater pada basin tipe solar still dengan tipe kaca penutup miring terhadap efisiensi. Tujuan dari penelitian ini adalah untuk menguji penambahan preheater untuk meningkatkan temperatur awal pada basin type solar still dengan tipe penutup kolektor miring terhadap efektivitas peningkatan produktivitas kondensat serta efisiensi dari distilator. Hasil penelitian menunjukkan bahwa preheater berfungsi untuk meningkatkan suhu air baku sebelum di alirkan ke dalam bak destilator; laju Destilasi 0,1086 1/m2.jam, efisiensi produk 0,0190\%, radiasi kaca 110,31 watt; radiasi alumunium yang terdapat di dalam bak 9,55 watt, pada pipa tembaga 19,1 watt, energi yang di serap plat 74,205 watt, energi yang di serap kolektor 9,5 watt, energy yang berguna 55,2 watt, efisiensi kolektor 0,743\%; dan efisiensi destilator $1,677 \%$, kalor uap zat $1,99 \mathrm{kkal} / \mathrm{jam}$. kg, kapasitas Produk 0,054 kg/ jam [4].

\section{TINJAUAN PUSTAKA}

\subsection{Kesetimbangan Energi}

Efisiensi alat destilasi air merupakan perbandingan dari energi berguna dengan energi panas yang dihasilkan oleh plat penyerap. Energi berguna merupakan energi panas yang digunakan dalam proses penguapan dan energi panas yang digunakan saat pengembunan. Untuk mengetahui efisiensi alat destilasi kita tinjau kesetimbangan energi pada alat destilasi.
Gambar 2.1. Diagram aliran energi.

Keterangan gambar :

IT = Intensitas matahari $\left(\mathrm{W} / \mathrm{m}^{2}\right)$.

$\mathrm{q}_{\mathrm{r}, 1}=$ Laju perpindahan panas radiasi dari kolektor kepermukaan dalam kaca (Watt).

$\mathrm{q}_{\mathrm{c}, 1}=$ Laju perpindahan panas konveksi dari uap air kepermukaan dalam kaca (Watt).

$\mathrm{q}_{\mathrm{c}, \mathrm{w}}=$ Laju perpindahan panas konveksi dari air ke uap air (Watt).

$\mathrm{q}_{\mathrm{k}}=$ Laju perpindahan panas konduksi dari kolektor ke dinding luar (Watt).

$\mathrm{q}_{\mathrm{r}, \mathrm{O}}=$ Laju perpindahan panas radiasi dari kaca ke lingkungan (Watt).

$\mathrm{q}_{\mathrm{c}, \mathrm{O}}=$ Laju perpindahan panas konveksi dari permukaan kaca ke lingkungan (Watt).

$\mathrm{T}_{\mathrm{a}}=$ Temperatur lingkungan $\left({ }^{\mathrm{O}} \mathrm{C}\right)$.

$\mathrm{T}_{\mathrm{w}}=$ Temperatur air $\left({ }^{\mathrm{O}} \mathrm{C}\right)$.

$\mathrm{T}_{\mathrm{c}}=$ Temperatur permukaan kaca $\left({ }^{\mathrm{O}} \mathrm{C}\right)$.

$\mathrm{T}_{\mathrm{sv}}=$ Temperatur uap air $\left({ }^{\mathrm{O}} \mathrm{C}\right)$.

$\mathrm{Tp}=$ Temperatur plat penyerap $\left({ }^{\mathrm{O}} \mathrm{C}\right)$.

Kesetimbangan energi dari sistem adalah sebagai berikut :

$\mathrm{q}_{\mathrm{c}, \mathrm{w}}+\mathrm{q}_{\mathrm{r}, 1}+\mathrm{q}_{\mathrm{c}, 1}+\left(\quad . \mathrm{I}_{\mathrm{T}} \cdot \mathrm{A}_{\mathrm{C}}\right)+\left(. \mathrm{I}_{\mathrm{T}}\right)=\mathrm{q}_{\mathrm{k}}+\mathrm{q}_{\mathrm{c}, \mathrm{O}}+$ $\mathrm{q}_{\mathrm{r}, \mathrm{O}}$

\subsection{Energi Berguna Kolektor}

Untuk perhitungan energi berguna dapat digunakan persamaan sebagai berikut :

$Q_{U}=Q_{\text {In }}-Q_{\text {Out }}$

$Q_{U}=\left(. I T \cdot A_{c} \cdot\right) \cdot\left(U_{L} \cdot A_{c}\left[\left(U_{L} \cdot A_{c} \cdot\left(T_{P}-T_{A}\right)\right]\right.\right.$ 
Dimana :

$\mathrm{I}_{\mathrm{T}} \quad=$ Intensitas matahari $\left(\mathrm{W} / \mathrm{m}^{2}\right)$,

$\mathrm{A}_{\mathrm{C}}=$ Luas plat penyerap $\left(\mathrm{m}^{2}\right)$

$=$ Koefisien absorptivitas plat penyerap,

$=$ Koefisien transmisivitas cover $/ \mathrm{kaca}$,

$\mathrm{U}_{\mathrm{L}}=$ Koefisien kerugian panas total $\left(\mathrm{W} / \mathrm{m}^{2}{ }^{2}{ }^{0}\right.$ C),

$\mathrm{T}_{\mathrm{P}}=$ Temperatur plat penyerap $\left({ }^{0} \mathrm{C}\right)$ dan

$\mathrm{T}_{\mathrm{A}}=$ Temperatur lingkungan $\left({ }^{0} \mathrm{C}\right)$.

\subsection{Energi Berguna Destilasi}

Untuk persamaan energi berguna destilasi dapat dilihat sebagai berikut :

$Q_{u-d}=\frac{m k \cdot h_{f g}}{t}$

Dimana :

$m k$ adalah produk air bersih per hari (liter/ hari),

$h_{f g}$ adalah panas laten penguapan $(\mathrm{kJ} / \mathrm{kg})$, $t$ adalah lamanya pengujian (s).

\subsection{Efisiensi Alat Destilasi}

Untuk perhitungan efisiensi alat destilasi air laut tenaga surya dapat digunakan persamaan :

$$
{ }_{d}=\frac{m k x h_{f g}}{A_{c} \times I_{T} x t} \times 100 \%
$$

Di mana :

$m k$ adalah total massa air kondensat $(\mathrm{kg})$, $h f g$ adalah panas laten penguapan $(\mathrm{kJ} / \mathrm{kg})$, $A c$ adalah luas plat penyerap $\left(\mathrm{m}^{2}\right)$, $I_{T}$ adalah intensitas radiasi matahari $\left(\mathrm{W} / \mathrm{m}^{2}\right)$, $t$ adalah lama waktu pengujian (s).

\subsection{Koefisien Kerugian Panas Total}

Proses perpindahan panas tidak semuanya dapat diubah menjadi energi lain, dan pada kolektor surya terjadi kerugian panas. Kerugian panas ini terjadi pada bagian atas, bagian bawah, dan bagian samping. Pada umumnya kerugian panas bagian samping diabaikan karena luasan kontak perpindahan panas dari plat penyerap ke samping sangat kecil dibandingkan dengan luasan plat penyerap pada bagian atas/bawah. Untuk koefisien kerugian panas total dapat ditulis sebagai berikut :
$\mathrm{U}_{\mathrm{L}}=\mathrm{U}_{\mathrm{t}}+\mathrm{U}_{\mathrm{b}}$

Dimana :

$\mathrm{U}_{\mathrm{L}}=$ koefisien kerugian panas total (W/ $\left.\mathrm{m}^{2} .{ }^{\mathrm{o}} \mathrm{C}\right)$,

$\mathrm{U}_{\mathrm{t}}=$ koefisien kerugian panas bagian atas $\left(\mathrm{W} / \mathrm{m}^{2}{ }^{\mathrm{O}} \mathrm{C}\right)$,

$\mathrm{U}_{\mathrm{b}}=$ koefisien kerugian panas bagian bawah $\left(\mathrm{W} / \mathrm{m}^{2} \cdot{ }^{\mathrm{O}} \mathrm{C}\right)$

\subsection{Analisis Kerugian Panas Bagian Atas}

Kerugian panas pada bagian atas terjadi secara konveksi, radiasi, dan konduksi.

Nilai koefisien kerugian panas bagian atas secara teori dapat didekati dengan persamaan berikut :

$\frac{1}{U_{t}}=R_{k-l}+R_{a-k}+R_{p-a}$

$=\frac{1}{h_{w i n}+h_{r-O}}+\frac{1}{h_{r-i}+h_{c-i}}+\frac{k}{L}$

Dimana :

$\mathrm{L}=$ tinggi air dalam basin $(\mathrm{m})$,

$\mathrm{k}=$ konduktivitas termal air $\left(\mathrm{W} / \mathrm{m} .{ }^{\mathrm{O}} \mathrm{C}\right)$.

Koefisien radiasi dalam $\left(\mathrm{h}_{\mathrm{r}-\mathrm{i}}\right)$ :

$h_{r-i}=\frac{\left(T_{w}^{4}-T_{c}^{4}\right)}{\left(\frac{1}{w}+\frac{1}{c}-1\right)\left(T_{w}-T_{c}\right)}$

Koefisien konveksi dalam $\left(\mathrm{h}_{\mathrm{c}-\mathrm{i}}\right)$ :

$h_{c-i}=1-0,0018(T-10) \frac{1,14 . \Delta T^{0,31}}{L^{0,07}}$

Koefisien konveksi angin $\left(\mathrm{h}_{\text {wind }}\right)$ :

$\mathrm{h}_{\text {wind }}=5,7+3,8 . \mathrm{V}$

Di mana :

$\mathrm{V}$ adalah kecepatan angin $(\mathrm{m} / \mathrm{s})$.

Koefisien radiasi luar $\left(\mathrm{h}_{\mathrm{r}-\mathrm{O}}\right)$ :

$h_{r-O}=\frac{{ }^{c} \cdot\left(T_{c}^{4}-T_{\text {langit }}^{4}\right)}{T_{c}-T_{\text {langit }}}$

Di mana $\mathrm{T}_{\text {langit }}=0,0552$ 


\section{Jurnal Ilmiah FLASH $\quad$ Volume 3 Nomor 2 Desember 2017}

\subsection{Analisis Kerugian Panas Bagian Bawah}

Kerugian panas bagian bawah terjadi secara konduksi dari plat penyerap ke panel bawah, sedangkan kerugian konveksi dan radiasi diabaikan karena nilainya lebih kecil dibandingkan dengan kerugian secara konduksi.

Nilai koefisien kerugian panas bagian bawah didekati dengan persamaan berikut :

$U_{b}=\frac{k_{i s o}}{L}$

Dimana :

$\mathrm{k}$ adalah konduktivitas termal isolasi $\left(\mathrm{W} / \mathrm{m} .{ }^{\circ} \mathrm{C}\right)$; $\mathrm{L}=$ tebal isolasi $(\mathrm{m})$.

\section{METODE PENELITIAN}

Penelitian ini dilakukan dengan menggunakan metode eksperimental nyata (true experimental) yaitu melakukan pengamatan untuk mencari data sebab akibat dalam suatu proses melalui eksperimen sehingga dapat mengetahui pengaruh penyerapan radiasi surya pada media tipe kotak dan bergelombang berbahan dasar stainless steel terhadap kemampuan destlasi air payau di pesisir pantai Seba, dimana dilakukan perlakuan yang sama pada kedua tipe penyerap ini yaitu waktu pengambilan data yang secara bersamaan untuk mengetahui performa maksimum.

Tujuan yang ingin dicapai dari penelitian skala laboratorium ini adalah untuk dapat meningkatkan performance destilasi air payau dengan menggunakan penyerap radiasi surya tipe kotak dan bergelombang dengan bahan dasar stainless steel. Selain itu, di bawah kedua plat penyerap diisi dengan batu kerikil dengan dasar pemikiran bahwa batu kerikil dapat menyimpan panas sehingga dapat mempercepat proses penguapan di dalam destilator itu sendiri. Instalasi penelitian berupa destilator tipe bergelombang dapat dilihat pada gambar $3.1 \mathrm{di}$ bawah ini :
Gambar 3.1. Instalasi Penelitian

Keterangan gambar :

IT = Intensitas matahari (W/m2)

qr,1 = Laju perpindahan panas radiasi dari kolektor kepermukaan dalam kaca (Watt).

$\mathrm{qc}, 1$ = Laju perpindahan panas konveksi dari uap air kepermukaan dalam kaca (Watt).

$\mathrm{qc}, \mathrm{w}=$ Laju perpindahan panas konveksi dari air ke uap air (Watt).

$\mathrm{qk}=$ Laju perpindahan panas konduksi dari kolektor ke dinding luar (Watt).

qr,O = Laju perpindahan panas radiasi dari kaca ke lingkungan (Watt).

$\mathrm{qc}, \mathrm{O}=$ Laju perpindahan panas konveksi dari permukaan kaca ke lingkungan (Watt).

$\mathrm{Ta}=$ Temperatur lingkungan $(\mathrm{O} \mathrm{C})$.

$\mathrm{Tw}=$ Temperatur air $(\mathrm{O} \mathrm{C})$.

$\mathrm{Tc}=$ Temperatur permukaan kaca $(\mathrm{O} \mathrm{C})$.

Tsv = Temperatur uap air $(\mathrm{O} \mathrm{C})$.

$\mathrm{Tp}=$ Temperatur plat penyerap $(\mathrm{O} \mathrm{C})$.

\subsection{Lokasi Penelitian}

Penelitian dosen pemula dengan judul pengaruh penyerapan radiasi surya pada media tipe kotak dan bergelombang berbahan dasar stainless steel terhadap kemampuan destilasi air payau di pesisir pantai Seba, akan dilaksanakan di depan Laboratorium Konversi, Jurusan Teknik Mesin, Politeknik Negeri Kupang.

\subsection{Variabel Penelitian}

Ada dua variabel yang dipergunakan dalam penelitian dosen pemula kali ini sebagai berikut: 
a. Variabel bebas. Ada dua variabel bebas yang digunakan yaitu sebagai berikut :

1. Waktu pengukuran suhu air wadah yaitu $08.00,09.00,10.00,11.00,12.00,13.00$, $14.00,15.00,16.00$ WITA

2.Penyerap radiasi tipe kotak dan tipe bergelombang, dimana keduanya dilapisi dengan batu kerikil.

b. Variabel terikat. Ada empat variabel terikat yang digunakan pada penelitian ini adalah :

1. Koefisien kerugian panas total

2. Energi berguna kolektor (J).

3. Energi berguna destilasi $(\mathrm{J})$.

4. Efisiensi alat (\%).

\section{HASIL DAN PEMBAHASAN}

Hasil dan pembahasan dapat ditampilkan dalam bentuk grafik sehingga berdasarkan kecendrungan pada grafik maka akan terlihat hubungan sebab akibat dan dapat ditarik beberapa kesimpulan. Adapun grafik yang dimaksud dapat dilihat pada gambar di bawah ini yaitu:

Gambar 4.1. Hubungan Antara Waktu Terhadap Energi Berguna Destilasi

Berdasarkan gambar 4.1 terlihat bahwa waktu pengambilan data sangat berpengaruh terhadap energi berguna destilasi yang dihasilkan oleh destilator. Hal ini terjadi karena energi berguna destilasi sangat dipengaruhi oleh nilai massa air hasil destilasi (kg), panas laten penguapan $(\mathrm{kJ} / \mathrm{kg})$ dan waktu (s) yang dibutuhkan untuk menghasilkan air hasil destilasi. Dari gambar juga terlihat bahwa energi berguna destilasi meningkat secara parabolik, di mana pada pukul 12 dan 13 WITA kedua desain penyerap panas ini menghasilkan energi tertinggi, hal ini terjadi karena intensitas cahaya tertinggi terjadi pada pukul 12 dan 13 WITA.

Selain itu, terlihat juga bahwa desain destilator dengan menggunakan penyerap tipe kotak dapat menghasilkan energi berguna yang lebih besar jika dibandingkan dengan desain destilator yang menggunakan penyerap tipe bergelombang. Hal ini terjadi karena tipe kotak memiliki luasan yang lebih besar, sehingga dapat menyerap panas lebih banyak sehingga dapat mempercepat proses pemanasan air di dalam destilator dan menghasilkan massa air hasil destilasi yang lebih banyak jika dibandingkan dengan desain tipe bergelombang. Pada desain tipe kotak maka energi berguna destilasi dapat menghasilkan energi rata-rata yakni sebesar $0.203 \mathrm{~kW}$, sedangkan pada desain tipe bergelombang maka energi berguna destilasi dapat menghasilkan energi rata-rata yakni sebesar $0.0762 \mathrm{~kW}$.

Gambar 4.2. Hubungan Antara Waktu Terhadap Efisiensi Alat Destilasi

Berdasarkan gambar 4.2 terlihat bahwa waktu pengambilan data sangat berpengaruh terhadap energi berguna destilasi yang dihasilkan oleh destilator. Hal ini terjadi karena energi berguna destilasi sangat dipengaruhi oleh nilai massa air hasil destilasi $(\mathrm{kg})$, panas laten penguapan $(\mathrm{kJ} / \mathrm{kg})$, luas penampang kaca $\left(\mathrm{m}^{2}\right)$, intensitas radiasi matahari $\left(\mathrm{W} / \mathrm{m}^{2}\right)$, dan waktu yang dibutuhkan untuk menghasilkan air hasil destilasi (s). Dari gambar juga terlihat bahwa efisiensi alat destilasi meningkat secara 
parabolik, di mana pada pukul 12 dan 13 WITA kedua desain penyerap panas ini menghasilkan efisiensi tertinggi, hal ini terjadi karena intensitas cahaya tertinggi terjadi pada pukul 12 dan 13 WITA.

Efisiensi alat destilasi tertinggi pada desain penyerap radiasi surya tipe kotak yakni sebesar $16.72 \%$ pada pukul 12 WITA. Sedangkan efisiensi alat destilasi tertinggi pada desain penyerap tipe bergelombang yakni sebesar $13.509 \%$ pada pukul 12 WITA.

\section{KESIMPULAN}

Dari hasil pembahasan yang telah dilakukan maka dapat ditarik kesimpulan bahwa:

1.Pada destilator dengan menggunakan penyerapan radiasi surya tipe kotak maka dapat menghasilkan efisiensi $16.72 \%$.

2.Pada destilator dengan menggunakan penyerapan radiasi surya tipe bergelombang maka dapat menghasilkan efisiensi $13.509 \%$.

\section{DAFTAR PUSTAKA}

[1]. Sumual. 2011. Pengaruh Kecepatan Angin Terhadap Produktivitas Air Kondensat Pada Peralatan Destilasi. Jurnal Pendidikan Teknologi dan Kejuruan. Volume 2, Nomor 2, hal 145-156. ISSN 2087-3581.
[2] Walangare, K.B.A; Lumenta, A.S.M; Wuwung, J.O; Sugiarso, B.A. 2013. Rancang Bangun Alat Konversi Air Laut Menjadi Air Minum Dengan Proses Destilasi Sederhana Menggunakan Pemanas Elektrik. e-Jurnal.

[3] Mulyanef; Sari M; Mario W; Nasution H. 2012. Kaji Eksperimental Untuk Meningkatkan Performansi Destilasi Surya Basin Tiga Tingkat Menggunakan Beberapa Bahan Penyimpan Panas. Jurnal Teknik Mesin Vol.2, No. 1, Oktober 2012 : 7-12.

[4]. Efendi M; Arifin M; Hasbi. 2012. Pengaruh Penggunaan Preheather Pada Basin Type Solar Stiil Dengan Type Kaca Penutup Miring Terhadap Efisiensi. Spektrum Industri, 2012, Vol. 10, No. 2 108-199. ISSN : 1963-6590. 